\title{
Circulating Insulin-Like Growth Factor-1 Level and Ovarian Cancer Risk
}

\author{
Yiyang Lia Yang Lia Jialing Zhang ${ }^{b}$ Changjun Zheng ${ }^{\mathrm{b}} \quad \mathrm{He}^{\mathrm{a}} \mathrm{Cu}^{\mathrm{b}}$ Huimei Yu \\ Limei Fan ${ }^{b}$ \\ aDepartment of Gynaecology and Obstetrics, the First Hospital of Jilin University, Changchun, \\ 'Department of Gynaecology and Obstetrics, the Second Hospital of Jilin University, Changchun, \\ 'Deparment of Pathology and Pathophysiology, School of Basic Medical Sciences, Changchun, China
}

\section{Key Words}

Ovarian cancer • Meta-analysis • Insulin-like growth factor-1

\begin{abstract}
Background/Aims: Insulin-like growth factor-1 (IGF-1) has an important role in cells' proliferation, differentiation and apoptosis, and it may be involved in carcinogenesis. Several epidemiological studies assessed the association between circulating IGF-1 level and ovarian cancer risk, but there was still no conclusive finding. Methods: A meta-analysis of published studies was performed to assess the association between circulating IGF-1 level and ovarian cancer risk. The summary odds ratio (OR) with $95 \%$ confidence interval $(95 \% \mathrm{CI})$ was calculated through meta-analysis to evaluate the strength of the association. Results: Five eligible studies were included into the meta-analysis, which involved a total of 2,028 cases of ovarian cancer and 4,625 controls. Meta-analysis of total 5 studies showed that high circulating IGF1 level was correlated with decreased risk of ovarian cancer $(\mathrm{OR}=0.84,95 \% \mathrm{CI} 0.74-0.97, \mathrm{P}$ $=0.013)$. After adjusting for heterogeneity, high circulating IGF-1 level was still correlated with decreased risk of ovarian cancer (OR $=0.83,95 \% \mathrm{CI} 0.72-0.95, \mathrm{P}=0.007)$. Subgroup analysis by age showed that circulating IGF-1 level was not correlated with ovarian cancer risk in women both less than 55 years and more than 55 years. However, after adjusting for heterogeneity, high circulating IGF-1 level was correlated with decreased ovarian cancer risk in women less than 55 years ( $\mathrm{OR}=0.82,95 \% \mathrm{CI} 0.72-0.94, \mathrm{P}=0.004)$. Conclusion: Our metaanalysis suggests that high circulating IGF-1 level may be correlated with decreased ovarian cancer risk, especially in women less than 55 years. More studies are needed to further assess the association between circulating IGF-1 level and ovarian cancer risk in the future.
\end{abstract}




\section{Introduction}

Ovarian cancer is the most prevalent gynecological malignancy in the world, and its incidence is increasing in both developed and developing countries [1,2]. Despite several medical advancements in the treatment of ovarian cancer, the survival rate has not improved significantly [3]. Many studies have been published to achieve the identification of effective biomarkers for ovarian cancer, such as carbohydrate antigen 125 (CA125) [4-7]. Identification of biomarkers for ovarian cancer not only can help us get a better understanding of the mechanism of ovarian cancer, but also can help us find some diagnostic biomarkers. Insulinlike growth factor-1 (IGF-1) has an important role in cells' proliferation, differentiation and apoptosis, and it may be involved in carcinogenesis [8-11]. Previous studies have shown that IGF-1 and its receptor are involved in cell's malignant transformation, and thereby the IGF system may be involved in the development or progression of ovarian cancer. Previous epidemiological studies have provided some evidence for the associations of circulating IGF1 level with colorectal cancer, prostate cancer, and breast cancer [12-14]. However, other studies have found that circulating IGF-1 level is not associated with lung cancer risk [15]. There were also several epidemiological studies performed to assess the association between circulating IGF-1 level and ovarian cancer risk, but there was still no conclusive finding [1623]. We thus performed a systematic review and meta-analysis of published epidemiological studies to evaluate the association between circulating IGF-1 level and ovarian cancer risk. We carried out the meta-analysis according to the Preferred Reporting Items for Systematic reviews and Meta-Analyses (PRISMA) statement [24].

\section{Materials and Methods}

\section{Data sources}

A systematic literature search of all published studies on the association between circulating IGF-1 level and ovarian cancer risk was performed. We searched Pubmed (1980-2015), Embase (1980-2015), and Web of Science (1980-2015) up to June 26 2015. The following search strategy was used: (Ovarian cancer or ovarian carcinoma) AND (IGF1, IGF-1, insulin-like growth factor 1, insulin-like growth factor I, or IGF-I). We also searched the reference lists of relevant reviews on the subject. No language limitation was used in the literature search.

\section{Selection criteria}

To be included into the meta-analysis, studies had to meet the following criteria: 1) prospective or retrospective cohort studies, nested case-control studies, or case-control studies; 2) Assessed the association between circulating IGF-1 level and ovarian cancer risk; 3) Reported risk estimates for the association between circulating IGF-1 level and ovarian cancer risk, such as odds ratio (OR) or relative risk (RR) with $95 \%$ confidence interval (95\%CI); 4) Reported risk estimates adjusted for possible confounding factors. Case-only studies were excluded, and case reports or reviews were also excluded. When two or more studies appeared to be from one research, we included the most recent publication, or the one containing the largest number of cases. Studies without usable data were also excluded.

\section{Data extraction}

Two investigators of the investigation teem performed the data extraction independently. They used a standardized data extraction form and extracted data from each included study, and disagreements were resolved by discussion. Data were extracted on first author, study design, time of follow-up, inclusion of cases, mean age of participants, control groups, matched factors, confounding factors, and risk estimates. The OR for highest vs. lowest group analysis was used in the meta-analysis.

Quality assessment

The quality of included studies was assessed using the Newcastle Ottawa scale (NOS), which was recommended by the Cochrane Non-Randomized Studies Methods Working Group [25]. There was a 
maximum of nine points for each included study, namely four points in the selection of participants, two points in the comparability of participants, and three points in the ascertainment of outcomes. Studies with 7-9 points were assigned to have excellent quality, studies with 4-6 points were assigned to have good quality, and studies with $0-3$ points were assigned to have low quality.

\section{Statistical analysis}

To assess the association between circulating IGF-1 level and ovarian cancer risk, the summary OR with $95 \% \mathrm{CI}$ was calculated through meta-analysis. As shown in the data extraction, the OR for highest vs. lowest group analysis was used in the meta-analysis. We used random-effect or fixed-effect meta-analysis to calculate the summary OR $[26,27]$. The between-study heterogeneity was assessed using Cochran's $Q$ statistic and the $\mathrm{I}^{2}$ statistic $[28,29]$. For the existence of obvious between-study heterogeneity $(\mathrm{P}<0.10$ for Cochran's $Q$ statistic, or $\mathrm{I}^{2}>50 \%$ ), random-effect model (DerSimonian and Laird model) was used [27]. When there was no obvious between-study heterogeneity ( $\mathrm{P}>0.10$ for Cochran's $\mathrm{Q}$ statistic, or $\mathrm{I}^{2}<50 \%$ ), the fixed-effect model (Mantel-Haenszel method) was used [26]. To test the credibility of the summary OR, single study was excluded by turns and the change in the pooled estimates was evaluated in the sensitivity analysis. Subgroup analyses were performed by study design and age. Publication bias was assessed by the inspection of funnel plot and computation of Egger's and Begg's tests. All statistical analyses were carried out using Stata statistical software (version 11.0. College Station, TX: Stata, 2010).

\section{Results}

\section{Study selection and characteristics}

The literature search in Pubmed, Embase, and Web of Science yielded a total of 659 references (Fig. 1). After reviewing titles and abstracts, most studies were excluded and only 10 papers were selected as potentially relevant studies, which were further assessed for eligibility by reading full-text [16-23, 30, 31]. Three studies were further excluded for caseonly studies $[18,21,30]$, and two studies were excluded for containing overlapping data [19, $20]$. Finally, five studies were included into the meta-analysis $[16,17,22,23,31]$. Table 1 showed the main characteristics of those 5 studies (Table 1). Four of those included studies were nested case-control studies, and the other one was case-control study (Table 1). The total number of ovarian cancer cases in each included study ranged from 59 to 1045 , and the number of controls ranged from 108 to 2,058 (Table 1). There were a total of 2028 cases of ovarian cancer and 4625 controls in the meta-analysis. Those 5 studies were published

Fig. 1. Flow chart showing the study selection in the meta-analysis.

659 Records found in literature search

Pubmed $(\mathrm{n}=253)$

Embase $(\mathrm{n}=211)$

Web of Science $(n=195)$

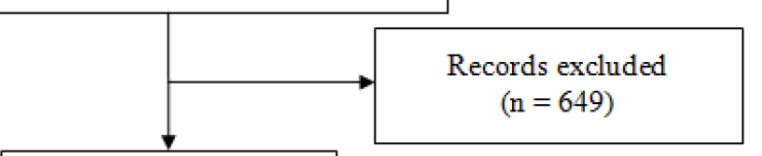

Full-text articles assessed for eligibility $(\mathrm{n}=10)$

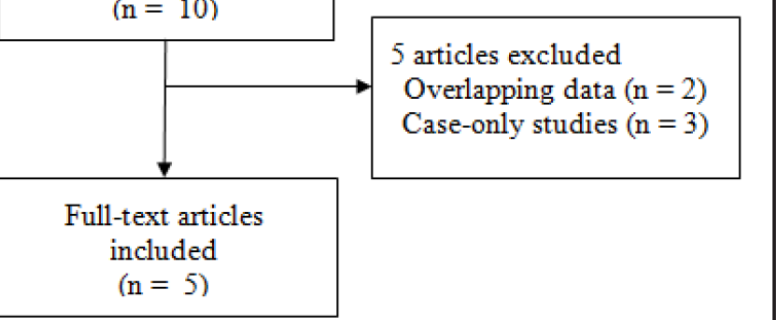


Table 1. Characteristics of five included studies in the meta-analysis (H vs. L, Higher level of IGF-1 vs. low level of IGF-1)

\begin{tabular}{|c|c|c|c|c|c|c|}
\hline Study & Design & $\begin{array}{l}\text { Country } \\
\text { (Recruitment period) }\end{array}$ & Subjects & tment & Comparison & $\begin{array}{l}\text { Quality } \\
\text { scores }\end{array}$ \\
\hline $\begin{array}{l}\text { Lukanova et al. } \\
2002[23]\end{array}$ & $\begin{array}{l}\text { Nested case- } \\
\text { control }\end{array}$ & $\begin{array}{l}\text { NYUWHS (New } \\
\text { York, USA; 1985-1991); } \\
\text { NSHDS (Umea, Sweden; } \\
\text { 1986-2001); ORDET } \\
\text { (Milan, Italy; 1987-1992) }\end{array}$ & $\begin{array}{l}132 \text { women with primary invasive } \\
\text { epithelial ovarian cancer diagnosed } \\
\text { at least } 1 \text { year after blood donation } \\
\text { were case subjects, and } 263 \text { matched } \\
\text { control subjects }\end{array}$ & Yes & $\begin{array}{l}\text { H vs. } \\
\text { L }\end{array}$ & 7 \\
\hline $\begin{array}{l}\text { Dal Maso et al. } \\
2004[22]\end{array}$ & Case-control & $\begin{array}{l}\text { Pordenone province, Italy } \\
(1999-2003)\end{array}$ & $\begin{array}{l}59 \text { women with ovarian cancer and } \\
108 \text { non-neoplastic controls admitted } \\
\text { to the same hospital network as cases }\end{array}$ & Yes & $\begin{array}{l}\text { H vs. } \\
\text { L }\end{array}$ & 6 \\
\hline $\begin{array}{l}\text { Tworoger et al. } \\
2007[31]\end{array}$ & $\begin{array}{l}\text { Nested case- } \\
\text { control }\end{array}$ & $\begin{array}{l}\text { NHS/NHSII (USA; 1996- } \\
\text { 2003); } \\
\text { WHS (USA; 1992-2004) }\end{array}$ & 222 cases and 599 matched controls & Yes & $\begin{array}{l}\text { H vs. } \\
\text { L }\end{array}$ & 8 \\
\hline $\begin{array}{l}\text { Ose et al. } 2015 \\
{[16]}\end{array}$ & $\begin{array}{l}\text { Nested case- } \\
\text { control }\end{array}$ & $\begin{array}{l}\text { Denmark, France, } \\
\text { Germany, Greece, Italy, } \\
\text { Netherlands, Spain, and } \\
\text { UK (1999-2003) }\end{array}$ & $\begin{array}{l}565 \text { ovarian cancer cases and } 1097 \\
\text { matched controls }\end{array}$ & Yes & $\begin{array}{l}\text { H vs. } \\
\text { L }\end{array}$ & 9 \\
\hline $\begin{array}{l}\text { Schock et al. } \\
2014[17]\end{array}$ & $\begin{array}{l}\text { Nested case- } \\
\text { control }\end{array}$ & $\begin{array}{l}\text { Finnish Maternity Cohort } \\
\text { (FMC), Finland (1983- } \\
\text { 2011) and NSMC, Sweden } \\
(1987-2013)\end{array}$ & $\begin{array}{l}1,045 \text { ovarian cancer cases and } 2,658 \\
\text { individually matched controls }\end{array}$ & Yes & $\begin{array}{l}\text { H vs. } \\
\text { L }\end{array}$ & 9 \\
\hline
\end{tabular}

Fig. 2. Meta-analysis of the association between circulating IGF-1 level and ovarian cancer risk.

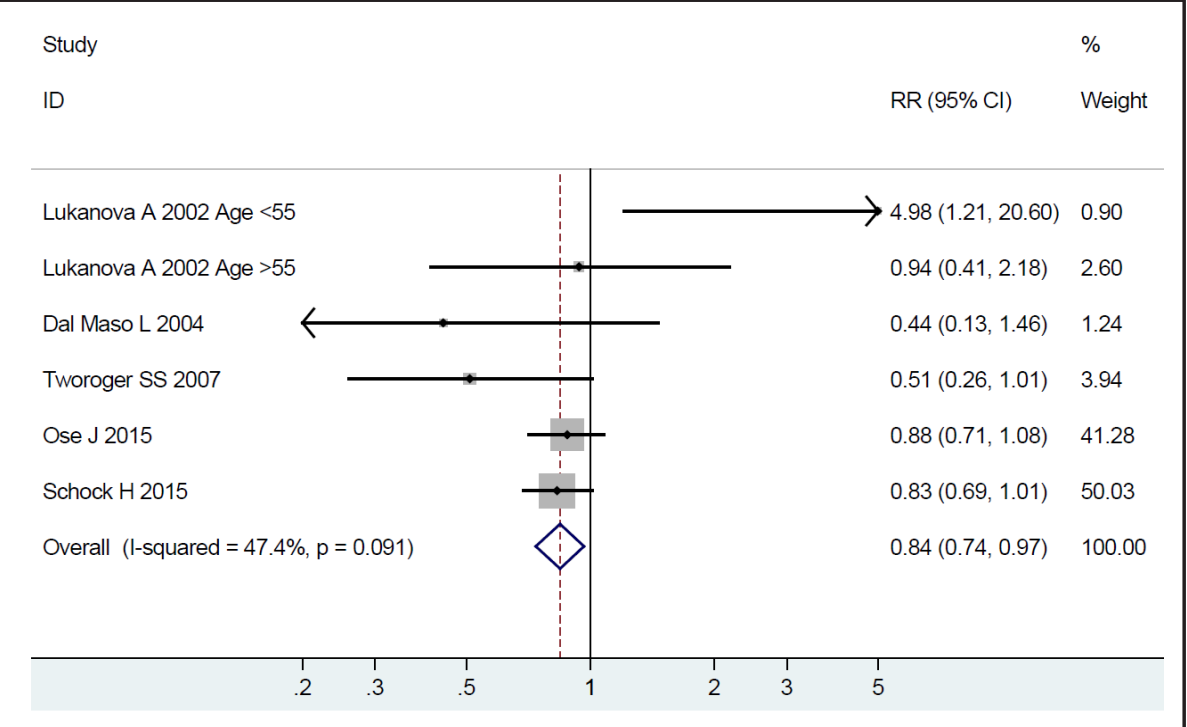

from 2002 to 2015, and all studies were performed in European countries or USA. Most controls in those included studies were healthy controls, and were matched to cases by age. All studies reported adjusted risk estimates, but the confounding factors were different from each other (Table 1). According to the quality scale, four studies had excellent quality with 7-9 stars, and one study had good quality (Table 1).

\section{Meta-analysis}

There was obvious between-study heterogeneity in the meta-analysis of total included studies $(\mathrm{P}=0.09)$. Meta-analysis of total 5 studies showed that high circulating IGF-1 level was correlated with decreased risk of ovarian cancer $(\mathrm{OR}=0.84,95 \% \mathrm{CI} 0.74-0.97, \mathrm{P}=0.013$ ) (Fig. 2). When using sensitivity analysis, the summary ORs were changed obviously by excluding single study by turns. When performing sensitivity analysis, we also observed the change of between-study heterogeneity. When performing sensitivity analysis by excluding Lukanova's study, there was obvious decrease in the between-study heterogeneity (from $47 \%$ to $10 \%$ ), and there was no statistically significant between-study heterogeneity ( $\mathrm{P}=$ 
Fig. 3. Meta-analysis of the association between circulating IGF-1 level and ovarian cancer risk after adjusting heterogeneity.

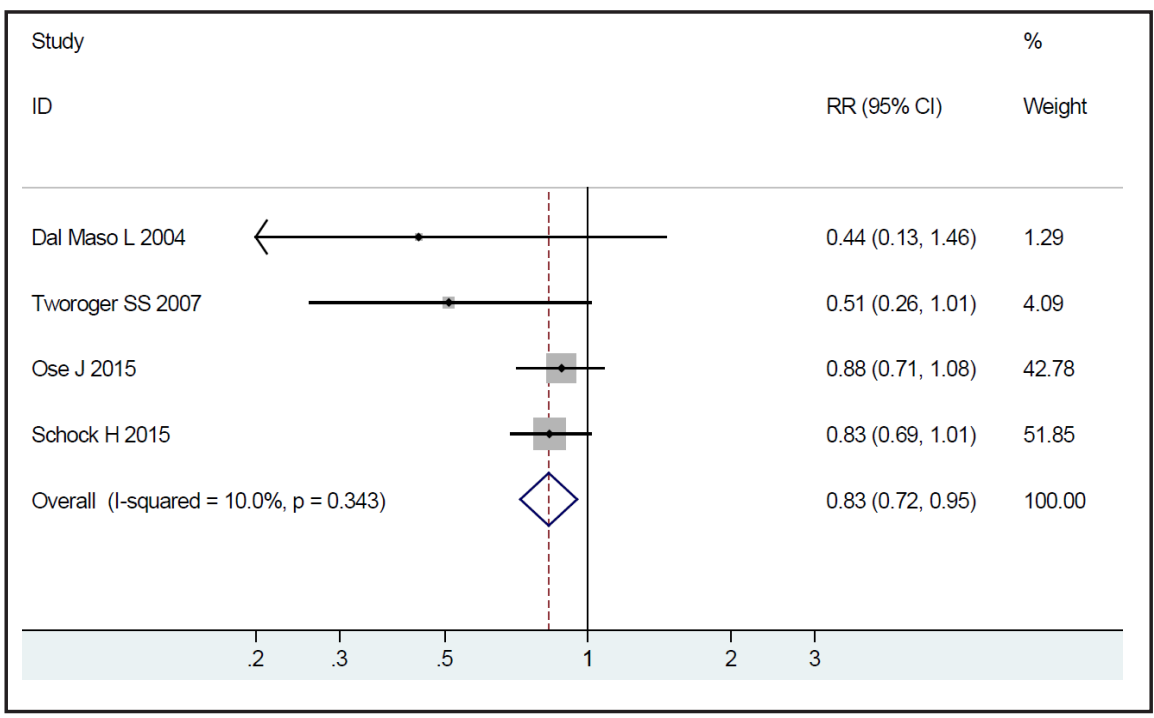

Fig. 4. High circulating IGF-1 level was correlated with decreased ovarian cancer risk in women less than 55 years.

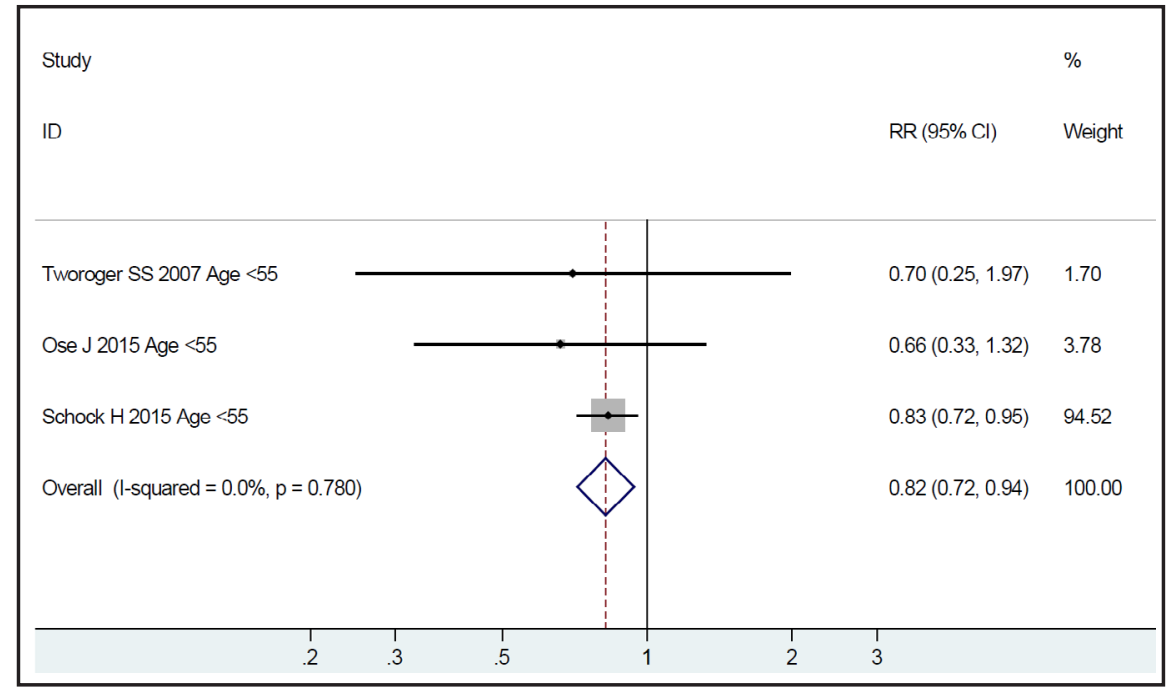

0.34). After adjusting for heterogeneity by excluding Lukanova's study, high circulating IGF-1 level was still correlated with decreased ovarian cancer risk $(\mathrm{OR}=0.83,95 \% \mathrm{CI} 0.72-0.95, \mathrm{P}$ $=0.007$ ) (Fig. 3).

In the subgroup analysis by study design, meta-analysis of 4 nested case-control studies showed that circulating IGF-1 level was not correlated with ovarian cancer risk $(\mathrm{OR}=0.86$, $95 \%$ CI $0.66-1.12, \mathrm{P}=0.26$ ). Subgroup analysis by age showed that circulating IGF-1 level was not correlated with ovarian cancer risk in women both less than 55 years and more than 55 years. However, after adjusting for heterogeneity by excluding Lukanova's study, high circulating IGF-1 level was correlated with decreased ovarian cancer risk in women less than 55 years $(\mathrm{OR}=0.82,95 \% \mathrm{CI} 0.72-0.94, \mathrm{P}=0.004)$ (Fig. 4). In addition, when using sensitivity analysis, the summary ORs were changed obviously by excluding single study by turns.

There was no indication of asymmetry in the funnel plot (Fig. 5), which was further supported by the results from the Egger's test $(P=0.86)$ and Begg's test $(P=0.71)$.

\section{Discussion}

In present study, we performed a systematic review and meta-analysis of published studies to evaluate the association between circulating IGF-1 level and ovarian cancer risk. 
Fig. 5. There was no indication of asymmetry in the funnel plot.

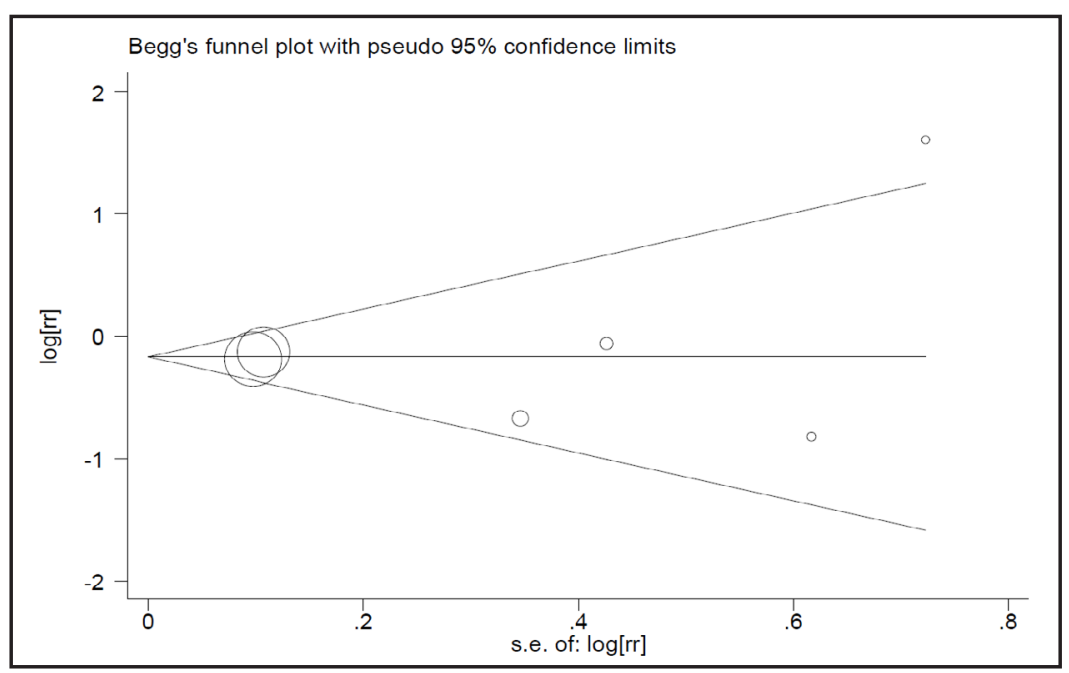

There were a total of 2028 cases of ovarian cancer and 4625 controls in the meta-analysis, which could help us to get a more appropriate evaluation on the association between circulating IGF-1 level and ovarian cancer risk. Meta-analysis of total 5 studies showed that high circulating IGF-1 level was correlated with decreased ovarian cancer risk $(\mathrm{OR}=0.84$, 95\%CI 0.74-0.97, $\mathrm{P}=0.013$ ). After adjusting for heterogeneity, high circulating IGF-1 level was still correlated with decreased ovarian cancer risk $(\mathrm{OR}=0.83,95 \% \mathrm{CI} 0.72-0.95, \mathrm{P}=$ 0.007). After adjusting for heterogeneity, high circulating IGF-1 level was correlated with decreased ovarian cancer risk in women less than 55 years $(\mathrm{OR}=0.82,95 \%$ CI $0.72-0.94$, $\mathrm{P}=0.004$ ). Therefore, our meta-analysis suggests that high circulating IGF-1 level may be correlated with decreased ovarian cancer risk, especially in women less than 55 years.

IGF-1 has important roles in promoting body growth, and it also has many other biological functions in different organs [32]. High circulating IGF-1 levels are also associated with various diseases, such as acromegaly [33, 34]. In addition, circulating IGF-1 has direct effects on cell's growth and proliferation, and high IGF-1 bioactivity may contribute to carcinogenesis and neoplastic progression [12-14]. High levels of serum IGF-1 has been identified to be associated with increased risk of colorectal cancer, prostate cancer, and breast cancer [12-14]. Besides, some agents targeting IGF-1 signaling are also promising in the treatment of some cancers $[13,35,36]$. Other factors in the IGF system are also likely to be potential therapeutic targets, and anticancer therapies aiming to target those factors are currently under investigation $[13,35,36]$.

High levels of serum IGF-1 are associated with increased risk of colorectal cancer, prostate cancer, and breast cancer [12-14], which also prove that IGF-1 is intensively involved in the carcinogenesis of common cancers [37,38]. It also has been proposed that IGF-1 may be involved in the carcinogenesis of ovarian cancer, and several epidemiological studies have been performed to assess the association between circulating IGF-1 level and ovarian cancer risk. Unfortunately, those studies failed to find a consistent finding on the association between circulating IGF-1 level and ovarian cancer risk. At present, there is still lack of compressive assessment for the impact of circulating IGF-1 level on ovarian cancer. In present, we showed a compressive assessment of the association between circulating IGF-1 level and ovarian cancer risk. The finding in the meta-analysis supports an obvious association between circulating IGF-1 level and ovarian cancer risk.

The meta-analysis suggests that higher levels of IGF-1 correlate with lower risk of ovarian cancer. However, previous studies have found a correlation between higher levels of IGF-1 and higher risk of colon cancer or breast cancer. It has been well accepted that IGF-1 may exert a direct effect by increasing cell's proliferation and inhibition of apoptosis, and experimental studies have shown that the malignant transformation of ovarian cells can be induced by overexpression of the IGF-1 receptor, which is IGF-I receptor-dependent pathway and has also been found in other types of cancers [39]. However, IGF-I may be involved in 
ovarian carcinogenesis through other mechanisms, which may be different from other types of cancers [39]. For example, IGF-I may influence ovarian cancer risk through the modulation of the bioavailability of sex steroid hormones, which have been implicated in the etiology of ovarian cancer. IGF-I has high affinity for both the IGF-I receptor and the estrogen receptors, and IGF-I is also a powerful negative regulator of estrogen bioavailability [40]. The above estrogen receptor-dependent pathway may explain the discrepancy on the correlations of IGF-1 with ovarian cancer and other types of cancers. However, more studies are needed to further explain this discrepancy.

Several limitations in the meta-analysis should also be acknowledged. Firstly, heterogeneity is an important factor that can influence the credibility of the pooled results in meta-analyses. In the present meta-analysis, we observed obvious between-study heterogeneity. There was obvious difference in the study design, which could result in the difference in the effect size reported from those included studies. In addition, owing to the lack of usable information, further subgroup analysis by types of ovarian cancer was not performed. Secondly, the circulating IGF-1 level changes obviously after menopause [41, 42]. In addition, IGF-1 levels also decreases significantly with age [43]. The association between circulating IGF-1 level and ovarian cancer may be different between premenopausal and postmenopausal women. In present meta-analysis, subgroup analysis by age showed that circulating IGF-1 level was not correlated with ovarian cancer risk in women both less than 55 years and more than 55 years. However, after adjusting for heterogeneity, high circulating IGF-1 level was correlated with decreased ovarian cancer risk in women less than 55 years $(\mathrm{OR}=0.82,95 \% \mathrm{CI} 0.72-0.94, \mathrm{P}=0.004)$ (Fig. 4). More studies are needed to explore the association between circulating IGF-1 level and ovarian cancer risk with different ages. Finally, even though we observed an obvious association between circulating IGF-1 level and ovarian cancer risk, current literature was unable to provide a conclusive finding owing to the limited number of included studies. The sample size in the meta-analysis was still not large enough to help us get a confidential estimation. More future prospective studies with large sample size are needed to clarify the association between circulating IGF-1 level and ovarian cancer risk.

In summary, our meta-analysis suggests that high circulating IGF-1 level may be correlated with decreased ovarian cancer risk, especially in women less than 55 years. More prospective studies with large sample size are needed to further assess the association between circulating IGF-1 level and ovarian cancer risk in the future.

\section{Acknowledgments}

This study was funded by the Postdoctoral Science Foundation of China (Nos. 2014T70298, 2013M541316, 2013M540256), and the National Natural Science Foundation of China (No. 81201268).

\section{Disclosure Statement}

The authors report no conflicts of interest in this work.

\section{References}

1 Wefers C, Lambert LJ, Torensma R, Hato SV: Cellular immunotherapy in ovarian cancer: Targeting the stem of recurrence. Gynecol Oncol 2015;137:335-342.

2 Mabuchi S, Kuroda H, Takahashi R, Sasano T: The pi3k/akt/mtor pathway as a therapeutic target in ovarian cancer. Gynecol Oncol 2015;137:173-179.

3 Garces AH, Dias MS, Paulino E, Ferreira CG, de Melo AC: Treatment of ovarian cancer beyond chemotherapy: Are we hitting the target? Cancer Chemother Pharmacol 2015;75:221-234. 


\section{Cellular Physiology Cell Physiol Biochem 2016;38:589-597 \begin{tabular}{l|l|l} 
DOI: 10.1159/000438652 & (C) 2016 S. Karger AG, Basel
\end{tabular} and Biochemistry Published online: February 05, 2016

4 Ohman AW, Hasan N, Dinulescu DM: Advances in tumor screening, imaging, and avatar technologies for high-grade serous ovarian cancer. Front Oncol 2014;4:322.

5 Leung F, Diamandis EP, Kulasingam V: Ovarian cancer biomarkers: Current state and future implications from high-throughput technologies. Adv Clin Chem 2014;66:25-77.

6 Ge T, Yin M, Yang M, Liu T, Lou G: Microrna-302b suppresses human epithelial ovarian cancer cell growth by targeting runx1. Cell Physiol Biochem 2014;34:2209-2220.

7 Teng Y, Zhao L, Zhang Y, Chen W, Li X: Id-1, a protein repressed by mir-29b, facilitates the tgfbeta1-induced epithelial-mesenchymal transition in human ovarian cancer cells. Cell Physiol Biochem 2014;33:717-730.

8 Sax AT, Jenkins DG, Devin JL, Hughes GI, Bolam KA, Skinner TL: The insulin-like growth factor axis: A biological mechanism linking physical activity to colorectal cancer survival. Cancer Epidemiol 2014;38:455-459.

9 Morris JK, George LM, Wu T, Wald NJ: Insulin-like growth factors and cancer: No role in screening. Evidence from the bupa study and meta-analysis of prospective epidemiological studies. Br J Cancer 2006;95:112117.

10 Yan S, Jiao X, Li K, Li W, Zou H: The impact of igf-1r expression on the outcomes of patients with breast cancer: A meta-analysis. Onco Targets Ther 2015;8:279-287.

11 Liu Z, Zhou K, Fu W, Zhang H: Insulin-like growth factor 1 activates pi3k/akt signaling to antagonize lumbar disc degeneration. Cell Physiol Biochem 2015;37:225-232.

12 Rinaldi S, Cleveland R, Norat T, Biessy C, Rohrmann S, Linseisen J, Boeing H, Pischon T, Panico S, Agnoli C, Palli D, Tumino R, Vineis P, et al.: Serum levels of igf-i, igfbp-3 and colorectal cancer risk: Results from the epic cohort, plus a meta-analysis of prospective studies. Int J Cancer 2010;126:1702-1715.

13 Key TJ, Appleby PN, Reeves GK, Roddam AW: Insulin-like growth factor 1 (igf1), igf binding protein 3 (igfbp3), and breast cancer risk: Pooled individual data analysis of 17 prospective studies. Lancet Oncol 2010;11:530-542.

14 Roddam AW, Allen NE, Appleby P, Key TJ, Ferrucci L, Carter HB, Metter EJ, Chen C, Weiss NS, Fitzpatrick A, Hsing AW, Lacey JV, Jr., Helzlsouer K, Rinaldi S, Riboli E, Kaaks R, Janssen JA, Wildhagen MF, Schroder FH, Platz EA, Pollak M, Giovannucci E, Schaefer C, Quesenberry CP, Jr., Vogelman JH, Severi G, English DR, Giles GG, Stattin P, Hallmans G, Johansson M, Chan JM, Gann P, Oliver SE, Holly JM, Donovan J, Meyer F, Bairati I, Galan P: Insulin-like growth factors, their binding proteins, and prostate cancer risk: Analysis of individual patient data from 12 prospective studies. Ann Intern Med 2008;149:461-471.

15 Chen B, Liu S, Xu W, Wang X, Zhao W, Wu J: Igf-i and igfbp-3 and the risk of lung cancer: A meta-analysis based on nested case-control studies. J Exp Clin Cancer Res 2009;28:89.

16 Ose J, Fortner RT, Schock H, Peeters PH, Onland-Moret NC, Bueno-de-Mesquita HB, Weiderpass E, Gram IT, Overvad K, Tjonneland A, Dossus L, Fournier A, Baglietto L, Trichopoulou A, Benetou V, Trichopoulos D, Boeing H, Masala G, Krogh V, Matiello A, Tumino R, Popovic M, Obon-Santacana M, Larranaga N, Ardanaz E, Sanchez MJ, Menendez V, Chirlaque MD, Travis RC, Khaw KT, Brandstedt J, Idahl A, Lundin E, Rinaldi S, Kuhn E, Romieu I, Gunter MJ, Merritt MA, Riboli E, Kaaks R: Insulin-like growth factor i and risk of epithelial invasive ovarian cancer by tumour characteristics: Results from the epic cohort. Br J Cancer 2015;112:162166.

17 Schock H, Fortner RT, Surcel HM, Grankvist K, Pukkala E, Lehtinen M, Lundin E: Early pregnancy igf-i and placental gh and risk of epithelial ovarian cancer: A nested case-control study. Int J Cancer 2015;137:439447.

18 Huang YF, Cheng WF, Wu YP, Cheng YM, Hsu KF, Chou CY: Circulating igf system and treatment outcome in epithelial ovarian cancer. Endocr Relat Cancer 2014;21:217-229.

19 Toriola AT, Surcel HM, Lundin E, Schock H, Grankvist K, Pukkala E, Chen T, Toniolo P, Lehtinen M, ZeleniuchJacquotte A, Lukanova A: Insulin-like growth factor-i and c-reactive protein during pregnancy and maternal risk of non-epithelial ovarian cancer: A nested case-control study. Cancer Causes Control 2011;22:16071611.

20 Peeters PH, Lukanova A, Allen N, Berrino F, Key T, Dossus L, Rinaldi S, van Gils CH, Bueno-de-Mesquita HB, Boeing H, Schulz M, Chang-Claude J, Linseisen J, Panico S, Sacerdote C, Palli D, Tumino R, Trichopoulou A, Trichopolos D, Bamia C, Larranaga N, Ardanaz E, Pera G, Quiros JR, Martinez-Garcia C, Navarro C, Bingham SA, Khaw KT, Clavel F, Tjonneland A, Olsen A, Overvad K, Tetsche MS, Lund E, Lundin E, Berglund G, Riboli E, Kaaks R: Serum igf-i, its major binding protein (igfbp-3) and epithelial ovarian cancer risk: The european prospective investigation into cancer and nutrition (epic). Endocr Relat Cancer 2007;14:81-90. 


\section{Cellular Physiology Cell Physiol Biochem 2016;38:589-597 \begin{tabular}{l|l}
\hline DOI: 10.1159/000438652 & (C) 2016 S. Karger AG, Basel
\end{tabular} and Biochemistry Published online: February 05, 2016

21 Lu L, Katsaros D, Wiley A, Rigault de la Longrais IA, Risch HA, Puopolo M, Yu H: The relationship of insulinlike growth factor-ii, insulin-like growth factor binding protein-3, and estrogen receptor-alpha expression to disease progression in epithelial ovarian cancer. Clin Cancer Res 2006;12:1208-1214.

22 Dal Maso L, Augustin LS, Franceschi S, Talamini R, Polesel J, Kendall CW, Jenkins DJ, Vidgen E, La Vecchia C: Association between components of the insulin-like growth factor system and epithelial ovarian cancer risk. Oncology 2004;67:225-230.

23 Lukanova A, Lundin E, Toniolo P, Micheli A, Akhmedkhanov A, Rinaldi S, Muti P, Lenner P, Biessy C, Krogh V, Zeleniuch-Jacquotte A, Berrino F, Hallmans G, Riboli E, Kaaks R: Circulating levels of insulin-like growth factor-i and risk of ovarian cancer. Int J Cancer 2002;101:549-554.

24 Liberati A, Altman DG, Tetzlaff J, Mulrow C, Gotzsche PC, Ioannidis JP, Clarke M, Devereaux PJ, Kleijnen J, Moher D: The prisma statement for reporting systematic reviews and meta-analyses of studies that evaluate health care interventions: Explanation and elaboration. Ann Intern Med 2009;151:W65-94.

25 Stang A. Critical evaluation of the Newcastle-Ottawa scale for the assessment of the quality of nonrandomized studies in meta-analyses. Eur J Epidemiol 2010; 25:603-605.

26 Mantel N, Haenszel W: Statistical aspects of the analysis of data from retrospective studies of disease. J Natl Cancer Inst 1959;22:719-748.

27 DerSimonian R, Laird N: Meta-analysis in clinical trials. Control Clin Trials 1986;7:177-188.

28 Cochran WG: The combination of estimates from different experiments. Biometrics 1954;10:101-129.

29 Higgins JP, Thompson SG, Deeks JJ, Altman DG: Measuring inconsistency in meta-analyses. BMJ 2003;327:557-560.

30 Brokaw J, Katsaros D, Wiley A, Lu L, Su D, Sochirca O, de la Longrais IA, Mayne S, Risch H, Yu H: Igf-i in epithelial ovarian cancer and its role in disease progression. Growth Factors 2007;25:346-354.

31 Tworoger SS, Lee IM, Buring JE, Pollak MN, Hankinson SE: Insulin-like growth factors and ovarian cancer risk: A nested case-control study in three cohorts. Cancer Epidemiol Biomarkers Prev 2007;16:1691-1695.

32 Kamenicky P, Mazziotti G, Lombes M, Giustina A, Chanson P: Growth hormone, insulin-like growth factor-1, and the kidney: Pathophysiological and clinical implications. Endocr Rev 2014;35:234-281.

33 Gadelha MR, Bronstein MD, Brue T, Coculescu M, Fleseriu M, Guitelman M, Pronin V, Raverot G, Shimon I, Lievre KK, Fleck J, Aout M, Pedroncelli AM, Colao A: Pasireotide versus continued treatment with octreotide or lanreotide in patients with inadequately controlled acromegaly (paola): A randomised, phase 3 trial. Lancet Diabetes Endocrinol 2014;2:875-884.

34 Misra M, Klibanski A: Endocrine consequences of anorexia nervosa. Lancet Diabetes Endocrinol 2014;2:581-592.

35 Limesand KH, Chibly AM, Fribley A: Impact of targeting insulin-like growth factor signaling in head and neck cancers. Growth Horm IGF Res 2013;23:135-140.

36 Salisbury TB, Tomblin JK: Insulin/insulin-like growth factors in cancer: New roles for the aryl hydrocarbon receptor, tumor resistance mechanisms, and new blocking strategies. Front Endocrinol (Lausanne) 2015;6:12.

37 Yang F, Chen H, Liu Y, Yin K, Wang Y, Li X, Wang G, Wang S, Tan X, Xu C, Lu Y, Cai B: Doxorubicin caused apoptosis of mesenchymal stem cells via p38, jnk and p53 pathway. Cell Physiol Biochem 2013;32:10721082.

38 Tian Z, Yao G, Song H, Zhou Y, Geng J: Igf2r expression is associated with the chemotherapy response and prognosis of patients with advanced nsclc. Cell Physiol Biochem 2014;34:1578-1588.

39 Pollak M: Insulin and insulin-like growth factor signalling in neoplasia. Nat Rev Cancer 2008;8:915-928.

40 Chen J, Zhao X, Ye Y, Wang Y, Tian J: Estrogen receptor beta-mediated proliferative inhibition and apoptosis in human breast cancer by calycosin and formononetin. Cell Physiol Biochem 2013;32:1790-1797.

41 Liu JM, Zhao HY, Ning G, Chen Y, Zhang LZ, Sun LH, Zhao YJ, Xu MY, Chen JL: Igf-1 as an early marker for low bone mass or osteoporosis in premenopausal and postmenopausal women. J Bone Miner Metab 2008;26:159-164.

42 Ardawi MS, Rouzi AA, Qari MH: Physical activity in relation to serum sclerostin, insulin-like growth factor-1, and bone turnover markers in healthy premenopausal women: A cross-sectional and a longitudinal study. J Clin Endocrinol Metab 2012;97:3691-3699.

43 Haden ST, Glowacki J, Hurwitz S, Rosen C, LeBoff MS: Effects of age on serum dehydroepiandrosterone sulfate, igf-i, and il-6 levels in women. Calcif Tissue Int 2000;66:414-418. 